\title{
Interferensi Gramatikal Bahasa Indonesia Dalam Percakapan Berbahasa Arab Santri PTYQM Kudus
}

\author{
Niswatush Sholihah \\ IAIN Salatiga, Jawa Tengah \\ Indonesia \\ niswah.am@gmail.com
}

\begin{abstract}
This study discusses the forms, causes and ways of overcoming Indonesian grammatical interference in Arabic conversations of the students of Pondok Tahfidz Yanbu'ul Qur'an Menawan (PTYQM) Kudus. This research is a qualitative research with a sociolinguistic approach. The method of providing data uses the listening and competent methods, and documentation. The method of data analysis uses the translational equivalent method where the determinant is another language, namely Indonesian. The results obtained are: Grammatical interference in the Arabic language in Arabic conversations in PTYQM Kudus, which consists of morphological and syntactic interference. Morphological interference that occurs in the form of affixation and reduplication processes. Whereas syntactic interference occurs at the level of phrases, clauses, and sentences. Interference at phrase level occurs at tarkïb ismy (nominal phrase), tarkīb fi'ly (verbal phrase), tarkīb 'adady (number phrase), tarkīb żarfy (front phrase), and tarkīb nida'iy (vocational phrase). Interference at the clause level consists of adding elements and using Indonesian elements. Interference at sentence level consists of changes in sentence structure, use of Indonesian elements, omission of elements, addition of elements, and incorrect use of particles. Factors causing grammatical interference consist of structural factors and non-structural factors. Structural factors are the differences between the grammatical system between Indonesian and Arabic. While non-structural factors such as: bilingual speakers and speech partners, Indonesian language habits carried on the santri Arabic, inadequate Arabic vocabulary, learning styles by translating, fear of being sanctioned, and compulsory language regulatory factors that apply at PTYQM. Interference can be overcome by: instilling awareness about the interference that occurs, giving attention and emphasis in drill students to use the correct form of interference, accustom students to use the correct Arabic structure and rules, write the correct form of interference occur on boards posted in places frequented by
\end{abstract}


Niswatush Sholihah

students, train students to translate Indonesian into Arabic contextually, provide knowledge of Arabic culture that is different from Indonesian.

Keyword: Grammatical interference, Arabic, Indonesian

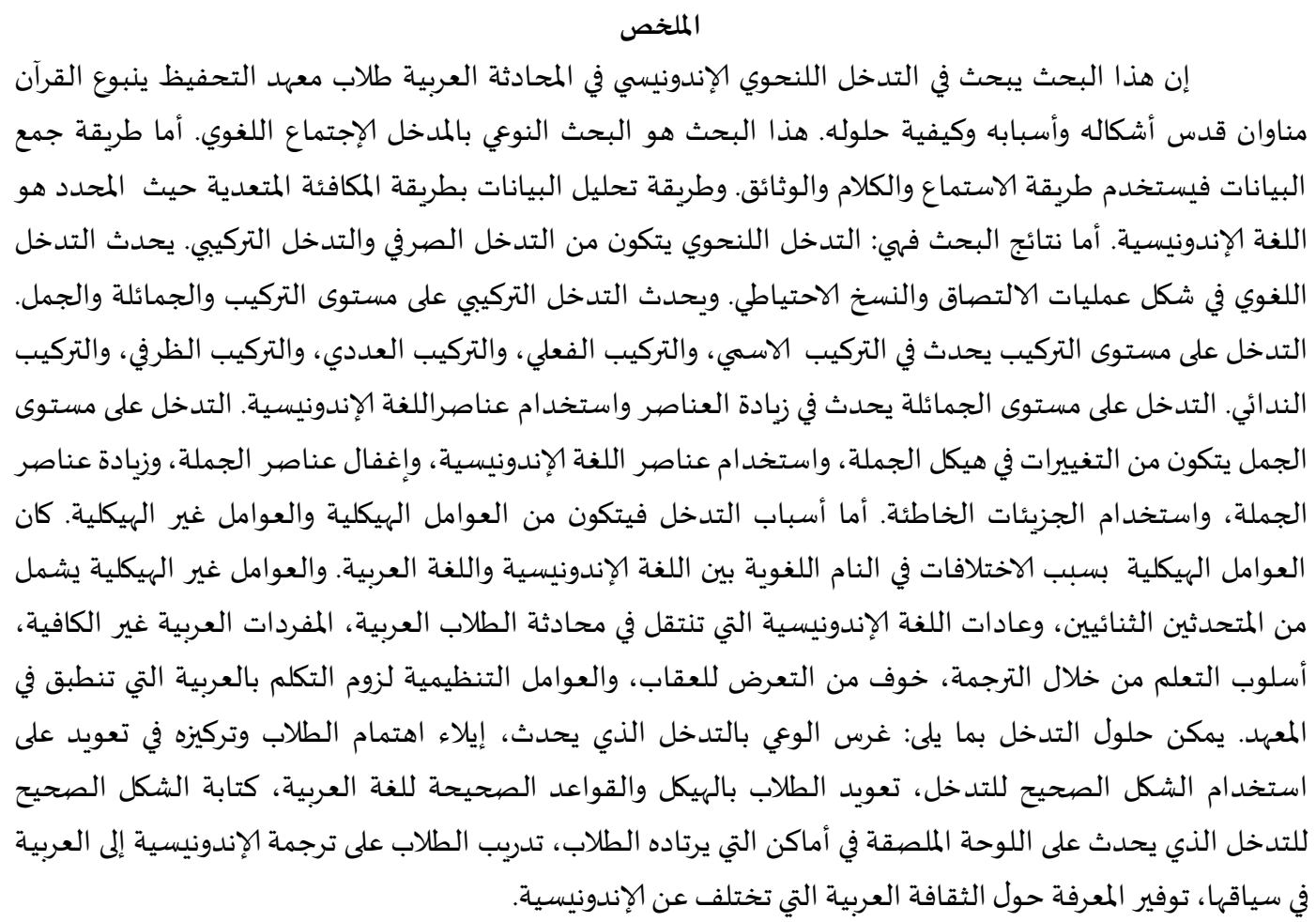

الكلمات المفتاحية: التدخل اللنحوي، اللغة الإندونيسية، اللغة العربية، طلاب معهد التحفيظ ينبوع القرآن مناوان قدس

\section{Abstrak}

Penelitian ini membahas bentuk, faktor penyebab dan cara mengatasi interferensi gramatikal bahasa Indonesia dalam percakapan berbahasa Arab santri Pondok Tahfidz Yanbu'ul Qur'an Menawan (PTYQM) Kudus. Penelitian ini merupakan penelitian kualitatif dengan pendekatan Sosiolinguistik. Metode penyediaan data menggunakan metode simak dan cakap, serta dokumentasi. Metode analisis data menggunakan metode padan translasional dimana penentunya adalah bahasa lain yaitu bahasa Indonesia. Hasil penelitian yang diperoleh adalah: Interferensi gramatikal bahasa Indonesia dalam percakapan berbahasa Arab santri Pondok Tahfidz Yanbu'ul Qur'an Menawan (PTYQM) Kudus terdiri dari interferensi morfologi dan interferensi sintaksis. Interferensi morfologi yang terjadi berupa proses afiksasi dan reduplikasi. Sedangkan interferensi sintaksis terjadi pada tingkat frasa, klausa, dan kalimat. Interferensi pada tingkat frasa terjadi pada tarkīb ismy (frasa nominal), tarkīb fi'ly (frasa verbal), tarkīb 'adady (frasa bilangan), tarkīb żarfy (frasa depan), dan tarkīb nida'iy (frasa vokasi). Interferensi pada tingkat klausa terdiri dari penambahan unsur dan penggunaan unsur bahasa Indonesia. Interferensi pada tingkat kalimat terdiri dari perubahan struktur kalimat, penggunaan unsur bahasa Indonesia, penghilangan unsur, penambahan unsur, dan penggunaan partikel yang salah. Faktor penyebab terjadinya interferensi gramatikal terdiri dari faktor struktural dan faktor non 
struktural. Faktor struktural berupa perbedaan antara sistem gramatikal antara bahasa Indonesia dan bahasa Arab. Sedangkan faktor non-struktural berupa: kedwibahasaan penutur dan mitra tutur, kebiasaan bahasa Indonesia terbawa pada bahasa Arab santri, tidak cukupnya kosakata bahasa Arab, gaya belajar dengan menerjemah, takut terkena sanksi, dan faktor peraturan wajib berbahasa yang berlaku di PTYQM Kudus. Interferensi dapat diatasi dengan cara: menanamkan kesadaran tentang interferensi yang terjadi, memberi perhatian dan penekanan dalam men-drill santri dalam menggunakan bentuk yang benar dari interferensi yang dilakukan, membiasakan santri menggunakan struktur dan kaidah bahasa Arab yang benar, menulis bentuk yang benar dari interferensi yang terjadi di papan yang ditempelkan di tempat-tempat yang sering didatangi santri, melatih santri untuk menerjemahkan bahasa Indonesia ke dalam bahasa Arab secara kontekstual, memberikan pengetahuan budaya Arab yang berbeda dengan bahasa Indonesia.

Kata kunci: Interferensi gramatikal, bahasa Indonesia, bahasa Arab, Santri PTYQM Kudus.

\section{Pendahuluan}

Perkembangan ilmu pengetahuan dan teknologi yang sangat pesat perlu diimbangi dengan pengetahuan dan kemampuan bahasa asing seperti bahasa Arab dan bahasa Inggris (I Dewa Putu Wijana dan Muhammad Rohmadi, 2010: 56). Oleh karena itu, lembaga pendidikan berusaha memperbaiki kualitasnya dengan menerapkan pembelajaran bahasa asing terutama bahasa Arab dan bahasa Inggris untuk membekali para peserta didik agar dapat bersaing di masa depan mereka. Salah satu pondok pesantren yang menerapkan kegiatan wajib berbahasa Asing adalah Pondok Tahfidz Yanbu'ul Qur'an Menawan Kudus. Bahasa Asing tersebut yaitu bahasa Arab untuk memahami ilmu agama dan al-Qur'an yang mereka hafalkan dan bahasa Inggris agar dapat mengakses ilmu pengetahuan modern. PTYQM menerapkan penggunaan bahasa Arab dan bahasa Inggris sebagai bahasa komunikasi santri sejak mereka masuk ke dalam lingkungan pondok. Penggunaan bahasa ini berlangsung secara formal di dalam kelas dan secara non formal di luar kelas. Kewajiban berbahasa Asing tersebut menyebabkan terjadinya saling pengaruh dalam diri santri yang berbahasa Indonesia dengan lingkungan pondok yang menggunakan bahasa Arab dan 
Inggris. Hal inilah yang menyebabkan terjadinya interferensi yang akan berpengaruh terhadap penggunaan dan kualitas bahasa Arab mereka.

Interferensi merupakan perubahan sistem suatu bahasa karena adanya persentuhan bahasa tersebut dengan unsur-unsur bahasa lain yang dilakukan oleh penutur yang bilingual (Weinreich, 1970: 1). Penggunaan serpihan kata, frasa, dan klausa dari bahasa lain dalam suatu kalimat juga dapat dianggap sebagai peristiwa interferensi (Abdul Chaer dan Leonie Agustina, 2010: 124). Interferensi terjadi sebagai akibat terbawanya kebiasaan-kebiasaan ujaran bahasa ibu atau dialek ke dalam bahasa atau dialek kedua (Nababan, 1993: 35). Gejala interferensi lumrah terjadi dalam proses pembelajaran bahasa kedua. Dalam teori pembelajaran bahasa disebutkan bahwa seseorang akan menggunakan pengalamannya terdahulu untuk memudahkan proses pembelajaran bahasa kedua. Termasuk pengalaman terdahulu tersebut adalah bahasa asli (Douglas Brown, 2008: 109). Bahasa asli ini kadang-kadang ditransfer secara negatif, sehingga menimbulkan terjadinya interferensi.

Salah satu contoh interferensi yang terjadi adalah ujaran santri ketika mengatakan ungkapan لَا نَقُلْن إِلَى مَنْ- مَنْ /ā taqul ilā man-man/ 'jangan bilang siapa-siapa'. Ungkapan ini mengandung kata tanya yang diulang. Dalam bahasa Arab tidak dikenal bentuk pengulangan kata, apalagi kata tanya. Namun dalam bahasa Indonesia, pengulangan kata lazim dilakukan terutama pada ragam lisan.

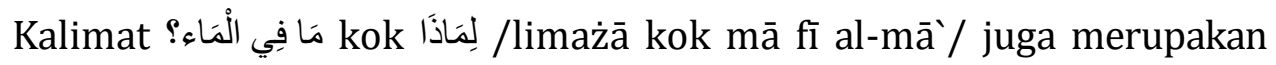
contoh interferensi. Kalimat ini mengandung partikel kok. Partikel ini berfungsi sebagai penegas. Partikel kok merupakan partikel bahasa Indonesia ragam nonstandar dan seharusnya tidak perlu disebutkan karena tanpa partikel itupun, kalimat tersebut sudah dapat dipahami pendengar.

Contoh di atas hanya sebagian kecil dari interferensi yang terjadi di pondok pesantren. Meskipun sering terjadi dalam percakapan santri, 
interferensi tidak dianggap sebagai pelanggaran yang akan mendapatkan sanksi dalam peraturan berbahasa di pondok pesantren. Hal ini terjadi karena dalam interferensi, hanya struktur ujarannya saja yang menyimpang, sedangkan redaksi keseluruhan ujaran menggunakan bahasa Arab. Selain itu, interferensi masih dimaklumi karena santri masih dalam taraf belajar dan untuk membangun keberanian dalam diri santri untuk berbahasa Arab. Keberanian ini dianggap penting sebagai fondasi awal keterampilan santri berbicara bahasa Arab yang tujuan akhirnya adalah untuk mencapai tingkat mahir berbahasa Arab, tak hanya mahir berbicara, tapi juga mendengar, membaca, dan menulis bahasa Arab.

Penelitian tentang interferensi, terutama yang terjadi dalam pembelajaran bahasa Arab, sudah dilakukan oleh beberapa peneliti. Namun, penelitian tersebut dirasa kurang memuaskan karena sebagian besar penelitian tersebut justru lebih banyak mendeskripsikan kesalahan berbahasa daripada menguraikan interferensi yang menjadi fokus kajiannya. Interferensi memang bagian dari kesalahan berbahasa, namun tidak semua kesalahan berbahasa adalah interferensi. Selain itu, Penelitian tentang pembelajaran bahasa Arab kebanyakan meneliti tentang model, strategi, dan metode. Penelitian yang berkaitan dengan Sosiolinguistik pada umumnya jarang dilakukan. Berdasarkan hal tersebut, penulis merasa perlu untuk melakukan penelitian tentang Interferensi gramatikal bahasa Indonesia dalam percakapan berbahasa Arab santri PTYQM Kudus.

Alasan pemilihan PTYQM adalah karena pondok ini terkenal dengan pondok bahasa yang semua santrinya menghafalkan al-Qur'an. Para santri pondok ini berasal dari berbagai wilayah di Indonesia yang menguasai bahasa Indonesia namun dihadapkan pada peraturan kewajiban berbahasa Arab dan Inggris yang berlaku di pondok sehingga memungkinkan terjadinya kontak bahasa yang menjadi akar terjadinya interferensi. Para santri lancar 
berbahasa Arab, namun struktur yang digunakan adalah struktur bahasa Indonesia.

\section{Landasan Teori}

\section{Pengertian Interferensi}

Interferensi adalah perubahan sistem suatu bahasa karena persentuhan bahasa tersebut dengan unsur-unsur bahasa lain yang dilakukan oleh penutur bilingual. Istilah interferensi ini pertama kali digunakan oleh Weinreich dalam bukunya Language in Contact, Findings and Problems. Dalam buku tersebut, ia memberikan definisi interferensi sebagai penyimpangan dari norma salah satu bahasa yang terjadi dalam tuturan bilingual sebagai hasil dari kebiasaannya menggunakan lebih dari satu bahasa (Abdul Chaer dan Leonie Agustina, 2010: 120).

Hartman dan Stork menyebut interferensi sebagai kekeliruan yang terjadi akibat terbawanya kebiasaan-kebiasaan ujaran bahasa ibu atau dialek ke dalam bahasa atau dialek kedua (Hartman dan Stork, 1972: 115). Tarigan memberikan definisi interferensi sebagai penggunaan sistem bahasa pertama dalam menggunakan bahasa kedua, sedangkan sistem tersebut tidak sama dengan sistem dalam bahasa kedua (Tarigan dan tarigan, 2011: 15). Sedangkan Parera mendefinisikan interferensi sebagai kesalahan yang diakibatkan oleh proses transfer yang tidak cocok antara bahasa pertama dan bahasa kedua (Parera, 1997: 121).

Beberapa pengertian tentang interferensi tersebut mengandung beberapa unsur yaitu:

a. Adanya penyimpangan pada sistem bahasa target

b. Penyimpangan tersebut dipengaruhi sistem bahasa sumber

c. Adanya kontak bahasa dalam diri penutur

d. Penutur merupakan seorang bilingual atau dwibahasawan 
e. Adanya perbedaan antara sistem bahasa sumber dengan bahasa target.

Dengan demikian, dapat disimpulkan bahwa interferensi adalah penyimpangan sistem bahasa penyerap karena pengaruh bahasa sumber yang berbeda dengan bahasa target, pada tuturan seorang bilingual.

Dalam proses interferensi ada tiga hal yang mengambil peranan, yaitu: bahasa yang memberi atau mempengaruhi disebut bahasa sumber atau bahasa donor, bahasa yang menerima disebut bahasa penyerap atau resipien, unsur yang diberikan disebut unsur serapan atau importasi (Chaer, Abdul dan Leonie Agustina, 2010: 126).

\section{Bentuk-bentuk Interferensi}

Weinreich membagi interferensi menjadi tiga, yaitu:

a. Interferensi bunyi (Phonic Interference)

Interferensi fonik muncul ketika seorang bilingual menuturkan sistem fonem bahasa kedua dengan sistem bahasa sumber, dan memperlakukannya dengan aturan fonetik bahasa sumber (Weinreich, 1970: 14. Ada empat tipe dalam interferensi fonik, yaitu:

a) Kurang dibedakannya fonem (Under-differentiation of Phonemes).

b) Perbedaan fonem yang berlebihan (over-differentiation of Phonemes).

c) Reinterpretasi fitur yang relevan.

d) Substitusi fonem.

b. Interferensi gramatikal

Ada beberapa bentuk interferensi gramatikal yang dapat diperkirakan terjadi, antara lain:

a) Penggunaan morfem atau tata bahasa sumber dalam ujaran bahasa keduanya.

b) Aplikasi relasi gramatikal bahasa sumber ke dalam ujaran bahasa kedua. 
c) Perubahan fungsi morfem bahasa kedua dengan meniru tatabahasa bahasa sumber.

d) Perbedaan kategori yang wajib ada.

e) Integrasi gramatikal pada kata yang ditransfer (Weinreich, 1970: 14).

c. Interferensi Leksikal

Interferensi leksikal berarti masuknya kata dari bahasa pertama (BI) kedalam bahasa kedua (B2) di tengah-tengah pembicaraan. Misal: penutur Indonesia yang belajar bahasa Arab mengucapkan ركبت /rakibtu mobil/ yang berarti saya naik mobil. Kata mobil merupakan kosakata bahasa Indonesia. Seharusnya kalimat itu berbunyi ركبت السيارة/rakibtu as-sayyārah/.

Untuk memfokuskan penelitian, tidak semua bentuk interferensi akan dibahas dalam penelitian ini. Peneliti hanya akan membahas tentang bentuk-bentuk interferensi gramatikal bahasa Indonesia yang terjadi dalam percakapan berbahasa Arab santri PTYQM Kudus.

\section{Faktor penyebab terjadinya Interferensi}

Weinreich membagi faktor yang mempengaruhi interferensi menjadi faktor struktural dan faktor non-struktural. Faktor struktural yang menyebabkan terjadinya interferensi adalah perbedaan sistem linguistik yang ada dalam bahasa-bahasa yang saling berkontak. Faktor struktural juga disebut faktor linguistik yaitu faktor yang berasal dari dalam bahasa itu sendiri. Faktor ini meliputi komponen-komponen bahasa yaitu fonologi, morfologi, sintaksis, dan semantik (1970: 1-4). Adapun faktor non-struktural terdiri dari keadaan psikologis dan sosiokultural kontak bahasa. Faktor non-strutural juga disebut faktor ekstralinguistik karena terletak di luar faktor linguistik. Faktor ekstralinguistik tersebut antara lain: kedwibahasaan peserta tutur, tipisnya kesetiaan pemakai bahasa penerima, tidak cukupnya kosakata 
bahasa penerima, menghilangnya kata-kata yang jarang digunakan, kebutuhan akan sinonim, prestise bahasa sumber dan gaya bahasa, dan terbawanya kebiasaan dalam bahasa ibu.

\section{Metode Penelitian}

Penelitian ini adalah penelitian deskriptif kualitatif dengan menggunakan pendekatan Sosiolinguistik sehingga menghasilkan data deskriptif berupa intereferensi gramatikal bahasa Indonesia dalam percakapan berbahasa Arab santri PTYQM Kudus. Penelitian ini merujuk pada teori interferensi Uriel Weinreich.

Metode penyediaan data menggunakan metode simak dengan teknik sadap sebagai teknik dasar, dan teknik rekam, serta teknik catat sebagai teknik lanjutannya, metode cakap dengan teknik pancing sebagai teknik dasar dan teknik rekam sebagai teknik lanjutannya, serta metode dokumentasi. Sedangkan analisis data menggunakan metode padan translasional di mana penentunya adalah bahasa lain yaitu bahasa Indonesia.

\section{Hasil Penelitian}

\section{Bentuk-bentuk Interferensi gramatikal bahasa Indonesia dalam percakapan berbahasa Arab santri PTYQM Kudus}

Interferensi gramatikal bahasa Indonesia dalam percakapan berbahasa Arab santri PTYQM Kudus terdiri dari interferensi morfologi dan interferensi sintaksis.

a. Interferensi morfologi

Interferensi morfologi yang peneliti temukan di PTYQM terjadi pada proses afiksasi dan reduplikasi.

1) Afiksasi

Bahasa Arab dan bahasa Indonesia memiliki proses afiksasi masing-masing, namun santri PTYQM sering mencampur morfem 
bahasa Arab dengan morfem Indonesia untuk menyampaikan maksud mereka. Para santri sering mengkombinasikan bentuk dasar bahasa Arab dengan afiks bahasa Indonesia. Proses ini disebut Indonesianisasi kata Arab, seperti pada contoh di bawah ini:

\begin{tabular}{|c|c|c|}
\hline Data interferensi & Transliterasi & Terjemah \\
\hline كَّطرًَا & /kemațaran/ & 'kehujanan' \\
\hline كَنَوْمًا & /kenauman/ & 'ketiduran' \\
\hline ككبيران & /kekabiran/ & 'kebesaran' \\
\hline كضغير ان & /keșaghïran & 'kekecilan' \\
\hline كَبيرِنْ & /kabïrin/ & 'besarin' \\
\hline صَغِغْيْرِنْ & /șaghīrin/ & 'kecilin' \\
\hline
\end{tabular}

Tabel 3. Data interferensi morfologi berupa afiksasi

Kata-kata di atas menunjukkan fenomena interferensi bahasa Indonesia dalam pembentukan kata bahasa Arab yang dilakukan santri. Para santri menyisipkan morfem yang berupa afiks bahasa Indonesia pada kata bahasa Arab mereka. Hal ini disebabkan karena kesulitan satri untuk mencari padanan afiks yang cocok dalam bahasa Arab. Oleh karena itu, santri menyisipkan morfem bahasa Arab.

2) Reduplikasi

Dalam tata bahasa Indonesia bentuk pengulangan kata lazim digunakan oleh pembicara. Namun dalam tata bahasa Arab, tidak dikenal bentuk reduplikasi yang berupa pengulangan kata. Karena terpengaruh tata bahasa Indonesia inilah, para santri sering melakukan pengulangan kata dalam ujaran bahasa Arab mereka. Bentuk-bentuk pengulangan kata tersebut antara lain:

\begin{tabular}{|c|c|c|}
\hline $\begin{array}{c}\text { Data } \\
\text { Interferensi }\end{array}$ & Transliterasi & Terjemah \\
\hline
\end{tabular}




\begin{tabular}{|c|c|c|}
\hline مَطَرْ - مَطَرًا & /mațar-mațaran/ & 'hujan-hujanan' \\
\hline لاَ مَاذَا - مَاذًا & /lā mażā-mażāa & \\
\hline لَا نَقَّلْ إِلْى مَنْ- مَنْ & $\begin{array}{l}\text { /lā taqul ilā man- } \\
\text { man/ }\end{array}$ & $\begin{array}{l}\text { 'jangan bilang siapa- } \\
\text { siapa' }\end{array}$ \\
\hline ثلاب طلاب طلاب & $\begin{array}{l}\text { /śumma jā̀a aṭ- } \\
\text { țullāb țullāb țullāb/ }\end{array}$ & $\begin{array}{l}\text { 'kemudian } \\
\text { para santri' }\end{array}$ \\
\hline
\end{tabular}

Tabel 4. Data interferensi morfologi berupa kata ulang

b. Interferensi sintaksis

1) Interferensi sintaksis tingkat frasa

a) Frasa verbal

Frasa verbal dalam bahasa Indonesia mempunyai aturan yang berbeda dari bahasa Arab. Namun, dalam percakapan berbahasa Arab santri PTYQM, ditemukan pola frasa verbal dengan struktur yang tidak sama dengan kaidah frasa verbal dalam bahasa Arab seperti:

\begin{tabular}{|c|c|c|}
\hline Data interferensi & Transliterasi & Terjemah \\
\hline خلاص ينتهي & /khalāș yantahī/ & 'sudah habis' \\
\hline اسكت فقط & /uskut faqaț/ & 'diam saja' \\
\hline سنَوْم أو لا & /sanaum awwalan/ & 'mau tidur dulu' \\
\hline الذي نوم & /al-lażī naum/ & 'yang tidur' \\
\hline
\end{tabular}

Tabel 5. Data interferensi pada frasa verbal (tarkīb fi'ly)

b) Frasa nominal (tarkīb ismy)

Dalam percakapan berbahasa Arab santri PTYQM, ditemukan beberapa frasa nominal yang dipengaruhi oleh bahasa Indonesia dan kaidah pembentukannya tidak sesuai dengan bahasa Arab standar.

\begin{tabular}{|l|l|l|}
\hline Data interferensi & Transliterasi & Terjemah \\
\hline
\end{tabular}




\begin{tabular}{|r|l|l|}
\hline أنت ذللك & /anta żālik/ & 'kamu itu' \\
\hline أنا فقط & /ana faqaț/ & 'saya saja' \\
\hline أنت كمان & /anta kamān/ & 'kamu lagi' \\
\hline
\end{tabular}

Tabel 6. Data interferensi pada frasa nominal (tarkīb ismy)

c) Frasa bilangan

Karena perbedaan dalam susunan frasa nominal bahasa Arab dan bahasa Indonesia pada bilangan 1 dan 2, santri sering menerapkan kaidah bahasa Indonesia dalam ungkapan frasa bilangan mereka, seperti:

\begin{tabular}{|r|l|l|}
\hline Data interferensi & \multicolumn{1}{|c|}{ Transliterasi } & \multicolumn{1}{|c|}{ Terjemah } \\
\hline واحد هكتار /wāhid hiktār/ & 'satu hektar' \\
\hline /حد حجرة /wāhid hujurah/ & 'satu kamar' \\
\hline
\end{tabular}

Tabel 7. Data interferensi pada tarkīb 'adady

d) Frasa depan

Frasa depan merupakan frasa yang terdiri dari kata depan diikuti oleh kata atau frasa. Dalam penelitian ini, penulis menemukan frasa depan yang terpengaruh oleh bahasa Indonesia santri seperti:

\begin{tabular}{|r|l|l|}
\hline Data interferensi & \multicolumn{1}{|c|}{ Transliterasi } & \multicolumn{1}{|c|}{ Terjemah } \\
\hline في أين & /fì aina?/ & 'di mana?' \\
\hline في هi & /fi hunā/ & 'di sini' \\
\hline في هناك /fi hunāka/ & 'di sana' \\
\hline
\end{tabular}

Tabel 8. Data interferensi pada frasa depan

e) Tarkīb nida'ìy

Tarkīb nida'iy merupakan frasa yang terdiri dari huruf nida' diikuti oleh kata atau frasa. Pada percakapan santri ditemukan interferensi dalam tarkīb nida'iy yang diterapkan. Para santri sering menggunakan kata sapaan Indonesia pada percakapan bahasa Arab mereka. 


\begin{tabular}{|c|c|c|}
\hline Data interferensi & Transliterasi & Terjemah \\
\hline Hai يوسف Hai & /Hai yusuf/ & 'Hai yusuf' \\
\hline جو هري، oh جو هري & $\begin{array}{l}\text { Jauhari, oh } \\
\text { Jauhari/ }\end{array}$ & 'Jauhari, oh Jauhari' \\
\hline
\end{tabular}

Tabel 9. Data interferensi pada tarkīb nidā ‘̄y

2) Interferensi sintaksis tingkat klausa

Klausa merupakan satuan sintaksis yang berada di atas satuan frasa dan di bawah satuan kalimat. Klausa terdiri atas satu verba atau frasa verbal saja, disertai satu atau lebih konstituen yang berhubungan dengan verba tadi (Verhaar, 2010: 162). Dalam banyak bahasa, predikat klausa ataupun kalimat harus selalu verbal. Sedangkan dalam bahasa-bahasa lain, predikat dapat berupa verbal ataupun nonverbal yaitu nominal. Dalam klausa yang berpredikat nominal, dibutuhkan predikat penyama yang menyamakan salah satu sifat atau suatu proses yang disebut pada tempat predikat. Untuk menghubungkan antara subjek dan predikat penyama tersebut, digunakan kopula atau kata penghubung di antara keduanya. Pemakaian kopula tersebut antara setiap bahasa berbeda-beda. Ada bahasa yang memakai kopula, ada yang tidak memakai kopula, dan ada yang memiliki dua kemungkinan, yaitu ada dan tidaknya kopula. Contoh bahasa Indonesia: Dia adalah Guru. Kopula adalah tidak berupa verbal.

\begin{tabular}{|c|l|l|}
\hline / في يوم الخميس & /fi yaumil khamis ba'da & 'pada hari Kamis \\
PBB & al-'așri maujud PBB/ & setelah așar ada PBB' \\
\hline
\end{tabular}

Tabel 10. Data interferensi sintaksis pada tingkat klausa

Klausa PBB في يوم الخميس بعد العصر موجود /fi yaumil khamis ba'da al-'așri maujūd PBB/ merupakan susunan khabar muqaddam dan جار mabtada' mu'akhkhar. Khabar didahulukan karena berbentuk /jar majrur/. Dalam kaidah gramatika bahasa Arab, khabar 
استقرّ Syibh al- jumlah/ menakdirkan lafadz شبه الجملة Serupa /istaqarra/ 'ada' untuk jumlah ismiyah dan menakdirkan lafadz كائن /kā’in/ 'ada' untuk jumlah ismiyah (Abu Faris ad-Daḥdāḥ, 1428 H: 79). Namun karena terbiasa menggunakan kopula dalam klausa bahasa Indonesia, para santri menambahkan kata موجود/maujūd/ untuk menghubungkan frasa في يوم الخميس بعد العصر /fi yaumil khamis ba'da al-'așri/dan kata PBB. Selain itu, klausa ini juga mengandung unsur bahasa Indonesia PBB yang merupakan akronim dari Peraturan Baris Berbaris. Akronim ini digunakan santri karena mereka kesulitan untuk mengungkapkannya dalam bahasa Arab.

3) Interferensi sintaksis tingkat kalimat.

Interferensi pada tingkat kalimat terdiri dari:

a) Perubahan struktur kalimat

Bahasa Arab dan bahasa Indonesia mempunyai pola dan struktur masing-masing. Dari data penelitian, ditemukan perubahan struktur kalimat bahasa Arab santri yang dipengaruhi oleh bahasa Indonesia. Perubahan struktur kalimat bahasa Arab santri meliputi:

- Perubahan letak kata tanya

Kalimat tanya dalam bahasa Arab selalu dimulai dengan kata tanya sedangkan bahasa Indonesia tidak mengharuskan memulai kalimat interogatif dengan kata tanya. Santri PTYQM sering tidak meletakkan kata tanya di awal kalimat seperti:

\begin{tabular}{|c|c|c|}
\hline Data interferensi & Transliterasi & Terjemah \\
\hline المستقبل؟ & $\begin{array}{l}\text { /satakūnu mā̇īā } \\
\text { fí al-mustaqbal?/ }\end{array}$ & $\begin{array}{l}\text { 'kamu mau jadi apa } \\
\text { nanti?' }\end{array}$ \\
\hline هني عمر كم دختَ & $\begin{array}{l}\text { /fì 'umri kam } \\
\text { dakhalta hunā?/ }\end{array}$ & $\begin{array}{l}\text { 'pada umur berapa } \\
\text { kamu masuk sini?' }\end{array}$ \\
\hline ذللك من؟ & /żālika man?/ & 'itu siapa?' \\
\hline
\end{tabular}




\begin{tabular}{|l|l|l|}
\hline هذا لماذ|؟ & /hāżā limāżāe// & 'ini kenapa?' \\
\hline طعامه كيف؟ & /ța'āmuhū & 'makanannya \\
& kaifa?/ & bagaimana?' \\
\hline
\end{tabular}

Tabel 11. Interferensi sintaksis perubahan letak kata tanya

- Kalimat Arab dengan struktur bahasa Indonesia

Perbedaan struktur kalimat bahasa Arab dan bahasa Indonesia sering membuat santri hanya mengalihbahasakan dari bahasa Indonesia ke dalam bahasa Arab tanpa mempedulikan kaidah struktur kalimat dalam bahasa Arab.

\begin{tabular}{|c|l|l|}
\hline $\begin{array}{c}\text { Data } \\
\text { interferensi }\end{array}$ & Transliterasi & \multicolumn{2}{|c|}{ Terjemah } \\
\hline أنت مدعو مع الأستاذ & $\begin{array}{l}\text { /anta mad'ū } \\
\text { ma'a al-ustāà/ }\end{array}$ & $\begin{array}{l}\text { 'kamu dipanggil sama } \\
\text { pak guru' }\end{array}$ \\
\hline هُقَامُ المَقِيْم & $\begin{array}{l}\text { /hum tuqāmu } \\
\text { al-muqìm/ }\end{array}$ & $\begin{array}{l}\text { 'mereka dibangunkan } \\
\text { orang yang bertugas } \\
\text { membangunkan' }\end{array}$ \\
\hline
\end{tabular}

Tabel 12. Data interferensi kalimat Arab dengan struktur bahasa Indonesia

Dalam kalimat pasif bahasa Indonesia, pelaku boleh disebutkan. Sedangkan dalam bahasa Arab, pelaku dalam kalimat pasif tidak boleh disebutkan. Alasan tidak disebutkannya pelaku dalam kalimat pasif bahasa Arab adalah karena: karena pelakunya sudah dikenal, pelakunya tidak diketahui, atau pelaku sengaja disembunyikan (al-Afghānī, Sa'id, 2003: 50-52). Bila pelaku disebutkan, maka harus menggunakan kalimat aktif. Salah satu alternatif untuk menerjemahkan kalimat pasif bahasa Indonesia ke dalam bahasa Arab adalah dengan menggunakan bentuk kalimat 
aktif bahasa Arab dengan objeknya didahulukan (maf'ul bih muqaddam).

Kasus lain perubahan struktur yang mengikuti struktur bahasa Indonesia. Kalimat-kalimat di bawah ini diterjemahkan langsung dari bahasa Indonesia.

\begin{tabular}{|c|c|c|}
\hline $\begin{array}{c}\text { Data } \\
\text { interferensi }\end{array}$ & Transliterasi & Terjemah \\
\hline أنا سنَوْم أولا & $\begin{array}{ll}\text { /ana sanaum } \\
\text { awwalan/ }\end{array}$ & $\begin{array}{ll}\text { 'aku mau tidur } \\
\text { dulu' }\end{array}$ \\
\hline طعامه خلاص ينتهي & $\begin{array}{l}\text { /ța'āmuhū khalās } \\
\text { yantahī/ }\end{array}$ & $\begin{array}{l}\text { 'makanannya sudah } \\
\text { habis' }\end{array}$ \\
\hline مَنْ اسمـه؟ & /man ismuhū?/ & 'siapa namanya?' \\
\hline هو يستعمل اللباس & $\begin{array}{l}\text { /huwa yasta'milu } \\
\text { al-libās/ }\end{array}$ & 'dia memakai baju' \\
\hline هناك موجود نفر & $\begin{array}{l}\text { /hunāka maujūd } \\
\text { nafar/ }\end{array}$ & 'disana ada orang' \\
\hline هنالك بسر عة اغتسلْ & $\begin{array}{l}\text { /hunāka bi sur'ah } \\
\text { ightasil qabla aț- } \\
\text { țābūr/ }\end{array}$ & $\begin{array}{l}\text { 'sana cepat mandi } \\
\text { sebelum antri' }\end{array}$ \\
\hline هو واحذ حجرة معي & $\begin{array}{l}\text { /huwa wāḥid } \\
\text { hujrah ma'̄̄/ }\end{array}$ & $\begin{array}{l}\text { 'dia satu kamar } \\
\text { denganku' }\end{array}$ \\
\hline
\end{tabular}

Tabel 13. Data interferensi kalimat Arab dengan struktur bahasa Indonesia

b) Penggunaan unsur bahasa Indonesia

Dalam percakapan berbahasa Arab santri PTYQM, ditemukan beberapa kalimat yang unsurnya tidak berasal dari bahasa Arab tetapi berasal dari bahasa Indonesia. Unsur yang paling banyak muncul berupa partikel bahasa Indonesia seperti kata kok, kan, oh, lah, eh, dan wah. Berikut ini merupakan 
interferensi sintaksis yang terjadi pada tingkat kalimat berupa penggunaan unsur bahasa Indonesia:

\begin{tabular}{|c|c|c|}
\hline $\begin{array}{c}\text { Data } \\
\text { interferensi }\end{array}$ & Transliterasi & Terjemah \\
\hline أَنْتَ غَنَيِّ، نَعَمْ kan؟ & $\begin{array}{l}\text { /anta ghany, na'am } \\
\text { kan?/ }\end{array}$ & 'kamu kaya, iya kan?' \\
\hline الْمَاء؟ لِمَاذَا & $\begin{array}{l}\text { /limażā kok mā fìh } \\
\text { al-mā'/ }\end{array}$ & $\begin{array}{l}\text { 'mengapa kok tidak } \\
\text { ada air?' }\end{array}$ \\
\hline kok أنَا لَمْ أَقْرَأ kok & /ana lam aqra' kok/ & $\begin{array}{l}\text { 'saya belum baca } \\
\text { kok' }\end{array}$ \\
\hline Oh هناك فرق Oh & /oh, hunāka farqun/ & 'oh, ada perbedaan' \\
\hline 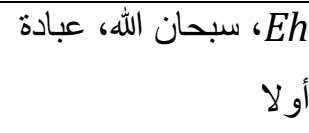 & $\begin{array}{l}\text { /eh, subhanallah } \\
\text { 'ibādah awwalan/ }\end{array}$ & $\begin{array}{l}\text { 'eh, subhanallah, } \\
\text { ibadah dulu' }\end{array}$ \\
\hline ثلاثة & $\begin{array}{l}\text { /eh, miftāh an-najāh } \\
\dot{s} a l a ̄ s \dot{s} \text { / }\end{array}$ & $\begin{array}{l}\text { 'eh, kunci sukses ada } \\
\text { tiga' }\end{array}$ \\
\hline 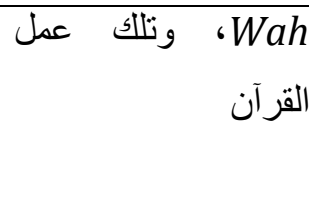 & $\begin{array}{l}\text { /wah, wa tilka 'amal } \\
\text { al-Qur'an/ }\end{array}$ & $\begin{array}{l}\text { 'wah, dan itu adalah } \\
\text { pengamalan al- } \\
\text { Qur'an' }\end{array}$ \\
\hline لا كذلك lah! & /lā każālik lah!/ & 'jangan begitu lah!' \\
\hline لا تيأس بذلك lah! & /lā taias biżālik lah/ & $\begin{array}{l}\text { 'jangan putus asa } \\
\text { lah!' }\end{array}$ \\
\hline 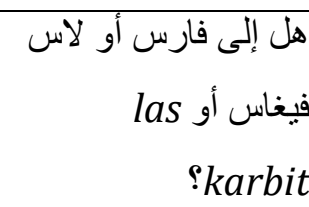 & $\begin{array}{l}\text { /hal ilā fāris au las } \\
\text { vegas au las karbit/ }\end{array}$ & $\begin{array}{l}\text { 'apakah ke Paris, Las } \\
\text { Vegas, atau Las } \\
\text { karbit' }\end{array}$ \\
\hline
\end{tabular}

Tabel 14. Data interferensi sintaksis berupa penggunaan unsur bahasa Indonesia

c) Penghilangan unsur

Berikut penghilangan unsur dalam kalimat bahasa Arab ini yang peneliti temukan: 
- Penghilangan subjek

Data penelitian menunjukkan bahwa banyak percakapan berbahasa Arab santri yang tidak menyebutkan subjeknya. Kalimat-kalimat tersebut antara lain:

\begin{tabular}{|c|c|c|}
\hline Data interferensi & Transliterasi & Terjemah \\
\hline عادة فقط & /'ädah faqaț/ & 'biasa saja' \\
\hline طويل جدَّا & /țawīl jiddan/ & 'panjang sekali' \\
\hline تعرف لا؟ & /ta'riflā?/ & 'tahu tidak?' \\
\hline خلص لمّا؟ & /khalāṣ lammā?/ & 'sudah belum?' \\
\hline
\end{tabular}

Tabel 15.Data interferensi sintaksis penghilangan subjek

- Penghilangan Predikat

Selain tidak menyebutkan subyek, para santri juga sering tidak menyebutkan predikat karena terpengaruh bahasa Indonesia ragam lisan yang sering tidak menyebutkan predikat seperti:

\begin{tabular}{|c|c|c|}
\hline $\begin{array}{c}\text { Data } \\
\text { interferensi }\end{array}$ & Transliterasi & Terjemah \\
\hline أَنَا أَمسِ مَعَ أَصْحَابِيْ & $\begin{array}{l}\text { /ana amsi ma'a } \\
\text { așhāby/ }\end{array}$ & $\begin{array}{ll}\text { 'saya } & \text { kemarin } \\
\text { bersama } & \text { sahabat- } \\
\text { sahabatku' } & \end{array}$ \\
\hline 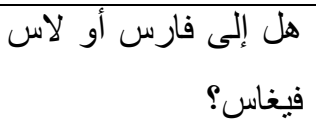 & $\begin{array}{l}\text { /hal ilā fāris au } \\
\text { las vegas?/ }\end{array}$ & $\begin{array}{l}\text { 'apakah ke Paris, atau } \\
\text { Las Vegas?' }\end{array}$ \\
\hline أنا فقط & /ana faqaț/ & 'saya saja' \\
\hline أنت فقط & /anta faqat// & 'kamu saja' \\
\hline أنت فقط ya ya & /anta faqațya/ & 'kamu saja ya' \\
\hline أنت كمانya..... & $\begin{array}{l}\text { /anta kaman } \\
\text { ya/ }\end{array}$ & 'kamu lagi ya' \\
\hline خلاص أو لمّا؟ & $\begin{array}{l}\text { /khalāṣau } \\
\text { lammā?/ }\end{array}$ & 'sudah atau belum?' \\
\hline
\end{tabular}




\begin{tabular}{|c|c|c|}
\hline خلاص جرس أو لمّا؟ & $\begin{array}{l}\text { /khalāṣ jaras au } \\
\text { lammā?? }\end{array}$ & $\begin{array}{l}\text { 'sudah bel atau } \\
\text { belum?' }\end{array}$ \\
\hline لا كذلك lah .... lah & $\begin{array}{l}\text { /lā każālik } \\
\text { lah.../ }\end{array}$ & 'jangan begitu lah' \\
\hline
\end{tabular}

Tabel 16. Data interferensi sintaksis penghilangan predikat

- Penghilangan Objek

Para santri juga sering tidak menyebutkan obyek dalam percakapan berbahasa Arab mereka, seperti data berikut ini:

\begin{tabular}{|c|c|c|}
\hline $\begin{array}{c}\text { Data } \\
\text { interferensi }\end{array}$ & Transliterasi & Terjemah \\
\hline ستشترك أم لا؟ & $\begin{array}{l}\text { /satasytariku am } \\
\text { lā?] }\end{array}$ & mau ikut atau tidak? \\
\hline ل لا تزيد؟ & /lā tazìd?/ & 'gak nambah?' \\
\hline من قال؟ & /man qāla?/ & $\begin{array}{ll}\text { 'siapa } & \text { yang } \\
\text { mengatakannya?' } & \end{array}$ \\
\hline
\end{tabular}

Tabel 17. Data interferensi sintaksis penghilangan objek

- Penghilangan kata tanya

Dalam bahasa Arab, kalimat tanya harus diawali dengan kata tanya. Karena terpengaruh dengan tata bahasa Indonesia yang tidak mengharuskan ada kata tanya dalam kalimat tanya, para santri sering tidak menyebutkan kata tanya.

\begin{tabular}{|c|c|c|}
\hline $\begin{array}{c}\text { Data } \\
\text { interferensi }\end{array}$ & Transliterasi & Terjemah \\
\hline ستتشرك أم لا؟ & $\begin{array}{l}\text { /satasytariku am } \\
\text { lā?/ }\end{array}$ & $\begin{array}{l}\text { 'mau ikut atau } \\
\text { tidak?' }\end{array}$ \\
\hline ذهبتَ بالطيارة؛ & $\begin{array}{l}\text { /żahabta bi aț- } \\
\text { țayyārah?/ }\end{array}$ & $\begin{array}{l}\text { 'kamu pergi dengan } \\
\text { pesawat?' }\end{array}$ \\
\hline تعقلَّت ست سنوات في التحفيظ ينبوع & $\begin{array}{lr}\text { /ta'allamta } & \text { sittu } \\
\text { sanawāt } & f i\end{array}$ & $\begin{array}{l}\text { 'kamu belajar enam } \\
\text { tahun di pondok }\end{array}$ \\
\hline
\end{tabular}




\begin{tabular}{|l|l|l|}
\hline القرآن & $\begin{array}{l}\text { ma'had al-tahfïz } \\
\text { yanbū'ul Qur'an?/ }\end{array}$ & $\begin{array}{l}\text { tahfidz Qur'an?' } \\
\text { Qunbu'ul }\end{array}$ \\
\hline
\end{tabular}

Tabel 18. Data interferensi sintaksis penghilangan kata tanya

Semua kalimat di atas meminta pengakuan dengan alternatif jawaban 'ya' atau 'tidak'. Karena itu, kata tanya yang tepat untuk ketiga kalimat tersebut adalah kata هَ هَ /hal/atau I/a/ (Nāṣif, Hifnī Bik, tt :108-109). Dalam bahasa Indonesia, kalimat interogatif yang meminta pengakuan dengan jawaban 'ya' atau 'tidak', atau 'ya' atau 'bukan' dapat dibentuk dengan cara memberi intonasi tanya pada kalimat tersebut (Chaer, $2009: 190$ ).

d) Penambahan unsur

Selain penghilangan unsur kalimat, ungkapan-ungkapan bahasa Arab santri juga mengalami penambahan unsur. Penambahan unsur tersebut terjadi karena pengaruh bahasa Indonesia seperti:

\begin{tabular}{|c|c|c|}
\hline $\begin{array}{c}\text { Data } \\
\text { interferensi }\end{array}$ & Transliterasi & Terjemah \\
\hline قلأتَ بأن في هناك & $\begin{array}{l}\text { /qulta bianna fì } \\
\text { hunāka al-ansyițāh/ }\end{array}$ & $\begin{array}{l}\text { 'kamu bilang disana } \\
\text { ada banyak kegiatan' }\end{array}$ \\
\hline هل فيه الماء هناك؟؟ & $\begin{array}{l}\text { /hal fihi al-mā' } \\
\text { hunāka?/ }\end{array}$ & $\begin{array}{l}\text { 'apakah ada air } \\
\text { disana?' }\end{array}$ \\
\hline الكثيّاف العصر هناك & $\begin{array}{l}\text { /ba'da al-'aṣri hunāka } \\
\text { al-kasysyāf/ }\end{array}$ & $\begin{array}{l}\text { 'setelah așar ada } \\
\text { pramuka' }\end{array}$ \\
\hline أنت غني، نعم كان؟ & $\begin{array}{l}\text { lanta ghany, na'am } \\
\text { kan?/ }\end{array}$ & 'kamu kaya, iya kan?' \\
\hline حماسة نعم! & /hamasah, na'am?/ & 'semangat ya!' \\
\hline
\end{tabular}

Tabel 19. data interferensi sintaksis berupa penambahan unsur

e) Penggunaan partikel yang salah. 
Para santri juga menggunakan partikel yang salah akibat pengaruh partikel bahasa Indonesia yang mereka terjemahkan tanpa melihat konteks, seperti:

\begin{tabular}{|c|c|c|}
\hline Data interferensi & Transliterasi & Terjemah \\
\hline أنت مدعو مع الأستاذ & $\begin{array}{l}\text { lanta mad'ū ma'a } \\
\text { al-ustāż/ }\end{array}$ & $\begin{array}{l}\text { 'kamu dipanggil } \\
\text { sama pak guru' }\end{array}$ \\
\hline
\end{tabular}

Tabel 20. interferensi sintaksis penggunaan partikel yang salah

Kesalahan yang sering terjadi adalah penggunaan partikel /ma'a/ akibat pengalihbahasaan kata 'sama' dalam bahasa Indonesia.

\section{Faktor-faktor penyebab terjadinya Interferensi gramatikal bahasa Indonesia dalam bahasa Arab}

Faktor-faktor penyebab terjadinya interferensi gramatikal bahasa Indonesia dalam percakapan berbahasa Arab santri PTYQM Kudus terdiri dari faktor struktural dan faktor non struktural.

1. Faktor struktural berupa perbedaan antara sistem gramatikal antara bahasa Indonesia dan bahasa Arab.

2. Faktor non-struktural berupa:

a. Kedwibahasaan penutur dan mitra tutur

b. Kebiasaan bahasa Indonesia terbawa pada bahasa Arab santri

c. Tidak cukupnya kosakata bahasa Arab

d. Gaya belajar dengan menerjemah

e. Takut terkena sanksi

f. Faktor peraturan wajib berbahasa yang berlaku di PTYQM Kudus.

3. Cara Mengatasi Interferensi gramatikal bahasa Indonesia dalam bahasa Arab

Interferensi dapat diatasi dengan cara:

1. Menanamkan kesadaran tentang interferensi yang terjadi 
2. Memberi perhatian dan penekanan dalam men-drill santri dalam menggunakan bentuk yang benar dari interferensi yang dilakukan

3. Membiasakan santri menggunakan struktur dan kaidah bahasa Arab yang benar

4. Menulis bentuk yang benar dari interferensi yang terjadi di papan yang ditempelkan di tempat-tempat yang sering didatangi santri

5. Melatih santri untuk menerjemahkan bahasa Indonesia ke dalam Arab bahasa secara kontekstual

6. Memberikan pengetahuan budaya Arab yang berbeda dengan bahasa Indonesia.

\section{Kesimpulan}

Interferensi gramatikal bahasa Indonesia dalam percakapan berbahasa Arab santri Pondok Tahfidz Yanbu'ul Qur'an Menawan (PTYQM) Kudus terdiri dari interferensi morfologi dan interferensi sintaksis. Interferensi morfologi yang terjadi berupa proses afiksasi dan reduplikasi. Sedangkan interferensi sintaksis terjadi pada tingkat frasa, klausa, dan kalimat. Interferensi pada tingkat frasa terjadi pada tarkīb ismy (frasa nominal), tarkīb fi'ly (frasa verbal), tarkīb 'adady (frasa bilangan), tarkīb żarfy (frasa depan), dan tarkīb nida'iy (frasa vokasi). Interferensi pada tingkat klausa terdiri dari penambahan unsur dan penggunaan unsur bahasa Indonesia. Interferensi pada tingkat kalimat terdiri dari perubahan struktur kalimat, penggunaan unsur bahasa Indonesia, penghilangan unsur, penambahan unsur, dan penggunaan partikel yang salah.

Faktor penyebab terjadinya interferensi gramatikal terdiri dari faktor struktural dan faktor non struktural. Faktor struktural berupa perbedaan antara sistem gramatikal antara bahasa Indonesia dan bahasa Arab. Sedangkan faktor non-struktural berupa: kedwibahasaan penutur dan mitra tutur, kebiasaan bahasa Indonesia terbawa pada bahasa Arab santri, tidak cukupnya kosakata bahasa Arab, gaya belajar dengan menerjemah, takut 
terkena sanksi, dan faktor peraturan wajib berbahasa yang berlaku di PTYQM Kudus.

Interferensi dapat diatasi dengan cara: menanamkan kesadaran tentang interferensi yang terjadi, memberi perhatian dan penekanan dalam men-drill santri dalam menggunakan bentuk yang benar dari interferensi yang dilakukan, membiasakan santri menggunakan struktur dan kaidah bahasa Arab yang benar, menulis bentuk yang benar dari interferensi yang terjadi di papan yang ditempelkan di tempat-tempat yang sering didatangi santri, melatih santri untuk menerjemahkan bahasa Indonesia ke dalam bahasa Arab secara kontekstual, memberikan pengetahuan budaya Arab yang berbeda dengan bahasa Indonesia. 


\section{Daftar Pustaka}

ad-Daḥdāh, Abu Faris. 1428 H. Syarh alfiyyah Ibn Mālik. Riyadh: Maktabah al 'Abīkān.

al-Afghānī, Sa'id. 2003. al-Mūjaz fì Qawā'id al-Lughah al-'Arabiyah. Beirut: Dār al-Fikr.

Brown, H.Douglas. 2008. Prinsip Pembelajaran dan Pengajaran Bahasa, terj. Noor Cholis dan Yusi Avianto Pareanom. Jakarta: Kedutaan Besar Amerika Serikat di Jakarta.

Chaer, Abdul dan Leonie Agustina. 2010. Sosiolinguistik: Perkenalan Awal. Jakarta: Rineka Cipta.

Chaer, Abdul. 2009. Sintaksis Bahasa Indonesia: Pendekatan Proses, Jakarta: Rineka Cipta.

Hartmann, R.R.K. dan F.C. Stork. 1972. Dictionary of Language and Linguistics. London: Applied Science Publisher Ltd.

Nababan, P.W.J. 1993. Sosiolinguistik: Pengantar Awal. Jakarta: Gramedia.

Nāṣif, Hifnī Bik dkk. tt. Qawā'id al-Lughah al-'Arabiyah. Semarang: Maktabah al-'Alawiyah.

Parera, Jos Daniel. 1997. Linguistik Edukasional: Metodologi Pembelajaran Bahasa, Analisis Kontrastif Antarbahasa, Analisis Kesalahan Berbahasa. Jakarta: Erlangga.

Tarigan, Henry Guntur dan Djago Tarigan. 2011. Pengajaran Analisis Kesalahan Berbahasa. Bandung: Angkasa.

Verhaar, J.W.M. 2010. Asas-asas Linguistik Umum. Yogyakarta: Gadjah Mada University Press.

Weinreich, Uriel. 1970. Language in Contact, Findings and Problems. The Hague: Mouton.

Wijana, I Dewa Putu dan Muhammad Rohmadi. 2010. Sosiolinguistik, Kajian Teori dan Analisis, Yogyakarta: Pustaka Pelajar. 